\title{
Sanfilippo A disease in the fetus
}

\section{P. S. HARPER,* K. M. LAURENCE,* A. PARKES,* F. S. WUSTEMAN,* H. KRESSE, K. VON FIGURA, $†$ M. A. FERGUSON-SMITH, $\ddagger$ D. M. DUNCAN, $\neq$ R. W. LOGAN, F. HALL, $\ddagger$ and P. WHITEMAN**}

\begin{abstract}
Summary. A pregnancy at risk for the Sanfilippo syndrome has been studied in which clear evidence was obtained from the study of amniotic fluid and fetal organs that the fetus was affected. Increased levels of heparan sulphate were found in amniotic fluid and fetal liver, while electronmicroscopy of cultured fetal fibroblasts and fetal liver showed abnormal cytoplasmic inclusions. ${ }^{35} \mathrm{SO}_{4}$ uptake studies of cultured fetal cells showed abnormal intracellular accumulation of mucopoly saccharide, while both cultured amniotic cells and fetal skin fibroblasts demonstrated deficiency of heparin sulphamidase, the enzyme responsible for the ' $A$ ' subtype of the disease. It is suggested that by use of a combination of these methods Sanfilippo A disease can now be diagnosed reliably in utero.
\end{abstract}

In the mucopolysaccharidoses cultured skin fibroblasts show excessive accumulation and prolonged turnover time of sulphated mucopolysaccharides which is due to the inactivity of enzymes involved in their degradation (Fratantoni, Hall, and Neufeld, 1968). The Sanfilippo syndrome (mucopolysaccharidosis III) has been demonstrated to be biochemically heterogeneous (Kresse et al, 1971). The inactivity of either a heparin (heparan sulphate) sulphamidase (Sanfilippo A disease-Kresse and Neufeld, 1972; Kresse 1973), or an N-acetyl- $\alpha$ D-glucosaminidase (Sanfilippo B disease-O'Brien, 1972; von Figura and Kresse, 1972), both enzymes necessary for normal heparan sulphate degradation, leads to the same clinical picture.

Increasing understanding of the metabolic basis of the mucopolysaccharidoses has led to the possibility of their prenatal detection, and successful prenatal diagnosis of the Hurler (mucopolysaccharidosis I) and Hunter (mucopolysaccharidosis II) diseases has been reported (Fratantoni et al, 1969; Crawfurd et al, 1973).

We should like to report details of a family in which a fetus affected by Sanfilippo A disease was clearly identified by a number of different methods,

\footnotetext{
Received 21 November 1973

* Welsh National School of Medicine and University College, Cardiff.

† Institute of Physiological Chemistry, University of Münster, Federal Republic of Germany.

‡ Royal Hospital for Sick Children, Glasgow.

** Institute of Child Health, London.
}

suggesting that reliable prenatal diagnosis of this disorder by amniocentesis is feasible.

\section{Family Details}

The pregnancy studied was the second of a healthy unrelated couple from South Wales, the mother being of Maltese origin. Their first child (Fig. 1), a male born in November 1966 was first investigated because of speech delay, behaviour disturbance, and mental retardation at

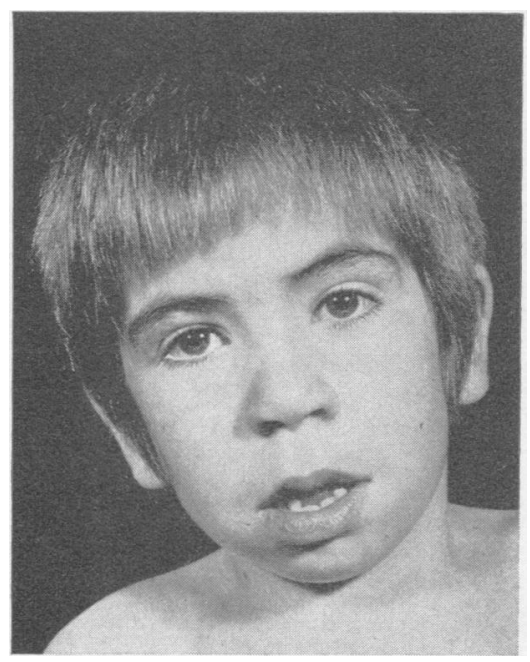

FIg. 1 Propositus aged 6 years. 
TABLE I

URINE MUCOPOLYSACCHARIDE EXCRETION OF AFFECTED SIB

(Total 24-hour volume $270 \mathrm{ml}$.)

\begin{tabular}{l|l|l}
\hline Heparan sulphate & $\begin{array}{l}\text { Hexuronic acid } \\
\text { Glucosamine }\end{array}$ & $\begin{array}{l}0.67 \mathrm{mmol} / 1 .(0.002) \\
0.62 \mathrm{mmol} / \mathrm{l} .(0.001)\end{array}$ \\
\hline $\begin{array}{l}\text { Chondroitin sulphates } \\
\text { including dermatan } \\
\text { sulphate }\end{array}$ & (Galactosamine) & $0.13 \mathrm{mmol} / \mathrm{l} .(0.046)$ \\
\hline & Total hexosamine & $0.75 \mathrm{mmol} / 1 .(0.150)$ \\
\hline
\end{tabular}

* Value for age-matched control.

age 5 years. Coarse facial features and hirsutism suggested the possibility of a mucopolysaccharidosis, but there was no hepatosplenomegaly or corneal clouding. Skeletal $x$-rays showed slight anterior beaking of the vertebrae but were not diagnostic of mucopolysaccharidosis. No inclusion bodies were seen on the blood film and the karyotype was normal. Initial screening tests for mucopolysaccharides were conflicting, but the diagnosis of Sanfilippo syndrome was established by the finding of large amounts of heparan sulphate in the urine (Table I).

At the time of diagnosis of the first child the mother was again 24 weeks pregnant. Since a confident prenatal diagnosis based on study of amniotic fluid could not be offered, and since there was insufficient time for culture of amniotic cells, a termination of the pregnancy on the basis of a 1 in 4 risk was offered and was carried out at 25 weeks' gestation.

\section{Materials and Methods}

Samples of amniotic fluid and fetal tissues were obtained at the time of termination of the pregnancy by hysterotomy. Tissues for biochemical studies were immediately frozen at $-20^{\circ} \mathrm{C}$ and kept at this temperature until analysis. Samples for electronmicroscopy were cut into $1-\mathrm{mm}^{3}$ fragments and fixed immediately in $6 \%$ glutaraldehyde in phosphate buffer for 2 hours at pH $7 \cdot 4$, and post-fixed in $2 \%$ osmium tetroxide in veronal acetate buffer ( $\mathrm{pH}$ 7.4). Tissues to be studied histologically were fixed in formalin and stained with haematoxylin and eosin, Alcian blue, and periodic acid-Schiff reagent.

Amniotic fluid cells and fetal skin fibroblasts were cultured initially in TC 199 medium with $10 \%$ fetal calf serum. The amniotic cell cultures were slow to grow and survived only two subcultures. Fetal skin fibroblasts grew rapidly and were readily established in subcultures. Fibroblasts to be studied by electronmicroscopy were trypsinized and spun at $500 \mathrm{~g}$ for $10 \mathrm{~min}$ before direct fixation in $2 \%$ osmium tetroxide in veronal acetate buffer at $\mathrm{pH} 7.4$ for 3 hours. Amniotic fluid mucopolysaccharides were analysed independently by three laboratories, whose methods in this case have been reported previously (Duncan et al, 1973; Ferguson-Smith et al, 1973; Whiteman, 1973). The mucopolysaccharide content of fetal tissues was measured after they had been extracted by ethanol, acetone and diethylether, and drying in air. The solid tissues were then digested by deoxyribonuclease and ribonuclease followed by overnight digestion with papain at $65^{\circ} \mathrm{C}$ (Scott, 1960). Mucopolysaccharides rendered soluble by this treatment and urinary mucopolysaccharides were fractionated on Dowex $1 \times 2\left(\mathrm{Cl}^{-}\right)$resin and assayed for hexuronic acid (Bitter and Muir, 1962), hexosamines (amino-acid Analyzer), and glucosamine residues with a free or Nsulphated amino group (Lagunoff and Warren, 1962).

Inorganic sulphate uptake by skin fibroblasts was measured by the method of Fratantoni et al (1968) using cultured fetal skin fibroblasts from the fetus at risk and from a 17-week normal fetus, each after two subcultures. Protein determinations were done by the method of Lowry et al (1951).

Determination of Heparin Sulphamidase and Glycoside Hydrolase Activities. Subcultures of skin fibroblasts and amniotic fluid cells were grown in Eagle's Minimum Essential Medium, supplemented with $10 \%$ fetal calf serum (Flow Laboratories), nonessential amino acids, and antibiotics as previously described (Kresse et al, 1971).

Skin fibroblasts grown to confluency in a $75-\mathrm{cm}^{2}$ plastic flask (Greiner) were harvested by trypsinization, suspended in $0.5 \mathrm{ml} .0 .075 \mathrm{~N} \mathrm{NaCl}$, and subjected to 10

TABLE II

MUCOPOLYSACCHARIDE CONTENT OF AMNIOTIC FLUID

\begin{tabular}{|c|c|c|}
\hline & $\begin{array}{l}\text { Fetus at Risk } \\
(\mathrm{mmol} / 1 .)\end{array}$ & $\begin{array}{l}\text { Control } \\
(\mathrm{mmol} / \mathrm{l} .)\end{array}$ \\
\hline $\begin{array}{l}\text { A. (Cardiff) } \\
\text { Total uronic acid } \\
\text { Total hexosamine } \\
\text { Heparan sulphate (expressed as glucosamine) } \\
\text { Lagunof and Warren Method } \\
\text { Amino-acid Autoanalyzer method }\end{array}$ & $\begin{array}{l}0.118 \\
0 \cdot 110 \\
0.021 \\
0.061\end{array}$ & $\begin{array}{l}0.052 \\
0.062 \\
0.004 \\
0.021\end{array}$ \\
\hline $\begin{array}{l}\text { B. (Glasgow) } \\
\text { Hexuronic acid (as glucuronolactone) }\end{array}$ & $0 \cdot 136$ & $0.059 \pm 0.021$ \\
\hline $\begin{array}{l}\text { C. }(\text { London }) \\
\text { Total } \\
\text { mucopolysaccharide }(\%)\left\{\begin{array}{l}\text { Chondroitin sulphates } \\
\text { Hyaluronic acid } \\
\text { Heparan sulphate }\end{array}\right.\end{array}$ & $\begin{array}{l}43 \% \\
5 \% \\
52 \%\end{array}$ & $\begin{array}{c}87 \% \\
13 \% \\
\text { None detected }\end{array}$ \\
\hline
\end{tabular}


FIG. 2. Cellulose acetate electrophoreis of amniotic fluid. (HS =heparan sulphate; HA=hyaluronic acid;

$\mathrm{CS}=$ chondroitin sulphate.)

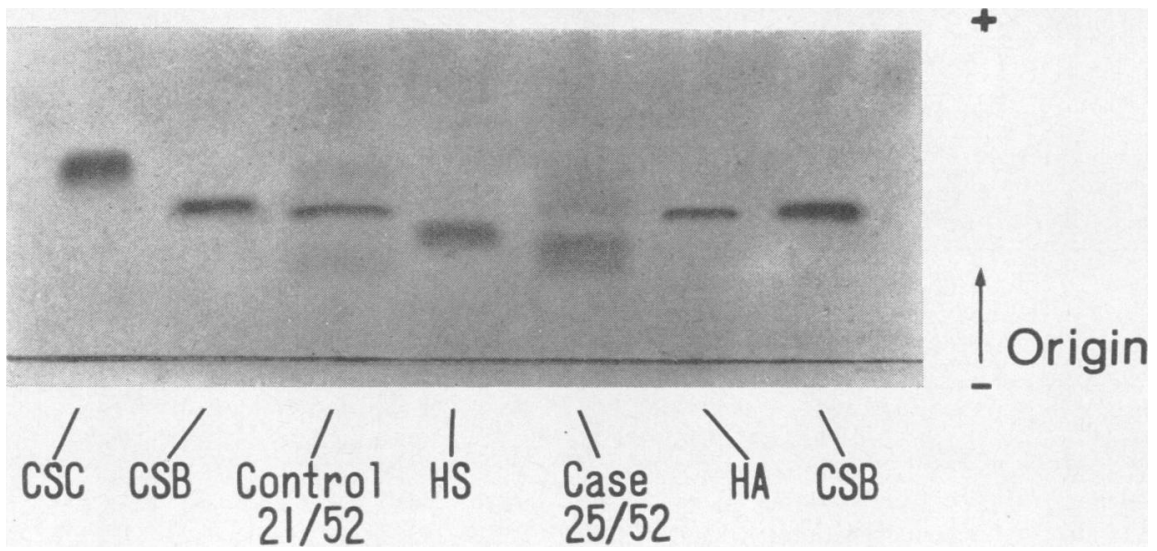

FIG. 2a. Electrophoresis in 0.1 m barium acetate, pH 8.0;100 V; $2 \mathrm{hr}$. (Method of Duncan et al, 1973).

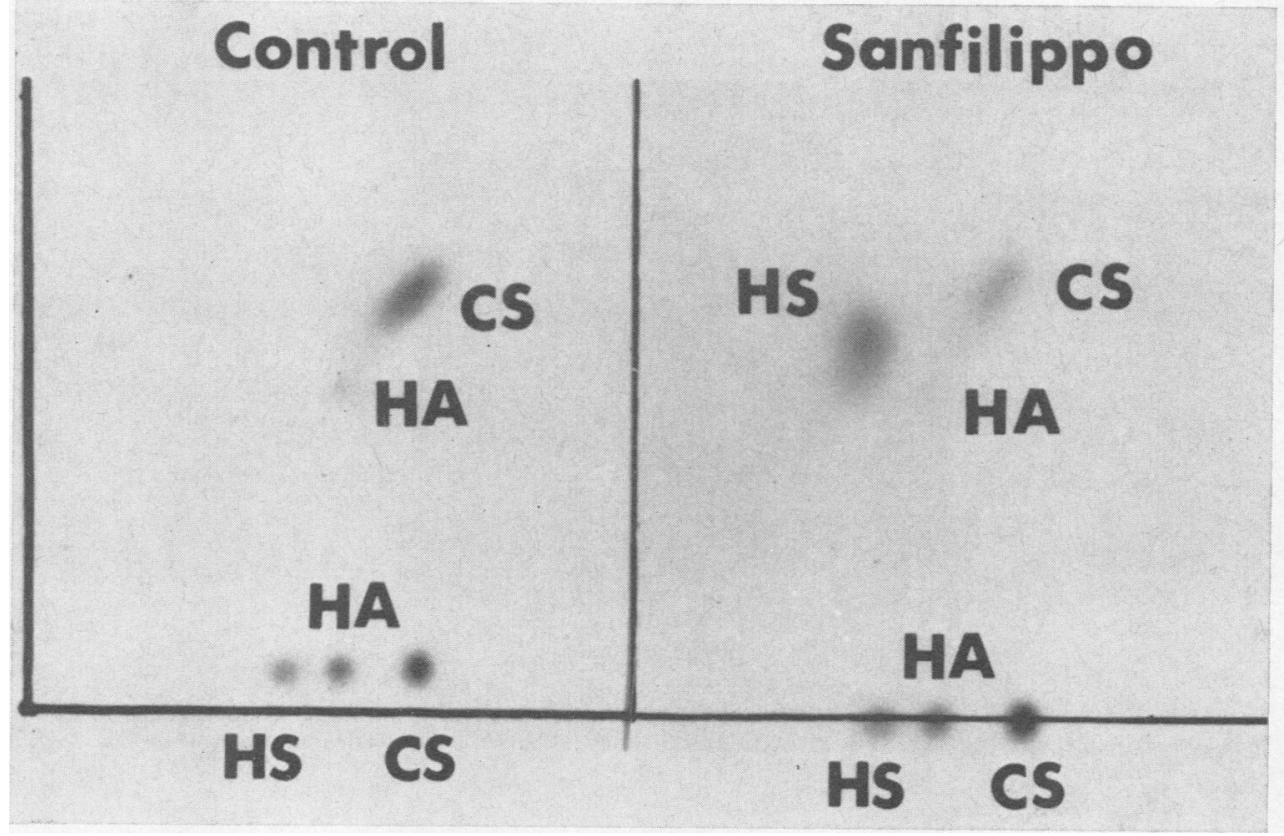

FIG. 2b. Two-dimensional electrophoresis (method of Whiteman, 1973).

cycles of freezing and thawing. Amniotic fluid cells from a $25-\mathrm{cm}^{2}$ flask were suspended in $0.2 \mathrm{ml} .0 .075$ $\mathrm{N} \mathrm{NaCl}$.

Heparin- $-{ }^{35} \mathrm{SO}_{4}$ (charge 32, specific activity 15 $\mu \mathrm{Ci} / \mathrm{mg}$ ) was purchased from Amersham-Buchler, o-nitrophenyl- $\alpha-\mathrm{D}-\mathrm{N}$-acetylglucosaminide from KochLight, and p-nitrophenylglycosides from Sigma; phenyl- $\alpha-\mathrm{D}-\mathrm{N}$-acetylglucosaminide was prepared according to the method of Weissmann (1966). From fetal organs a $20 \%$ homogenate was made in $0 \cdot 15 \mathrm{~N} \mathrm{NaCl}$ by means of an Ultraturrax. For enzyme measurements a clear supernatant was obtained after centrifugation for 20 mins at $75,000 \mathrm{~g}$.

The incubation mixture for the determination of heparin sulphamidase activity was as follows (values for organ extracts are given in parentheses): 50 (50) $\mu 1$. cell homogenate, $0.1 \mathrm{M}$ acetate buffer, $\mathrm{pH} 5 \cdot 0,0.02 \% \mathrm{NaN} 3$, 7(15) $\mu \mathrm{g}$ heparin- $\mathrm{N}^{35} \mathrm{SO}_{4}$, final volume 65 (80) $\mu 1$. 
TABLE III

MUCOPOLYSACCHARIDE CONTENT OF FETAL ORGANS

( $\mu$ mol uronic acid/g dry tissue)

\begin{tabular}{l|c|c|c|c}
\hline \multirow{2}{*}{ Site } & \multicolumn{2}{|c|}{ Fetus at Risk } & \multicolumn{2}{c}{ Control Fetus } \\
\cline { 2 - 5 } & $\begin{array}{l}\text { Heparan Sulphate } \\
\text { Fraction }\end{array}$ & $\begin{array}{c}\text { Chondroitin Sulphate } \\
\text { Fraction }\end{array}$ & $\begin{array}{c}\text { Heparan Sulphate } \\
\text { Fraction }\end{array}$ & $\begin{array}{c}\text { Chondroitin Sulphate } \\
\text { Fraction }\end{array}$ \\
\hline Liver & $15 \cdot 9$ & $5 \cdot 7$ & 0.50 & $7 \cdot 9$ \\
Brain & 3.25 & 4.8 & 1.48 & 5.5 \\
Spleen & 4.2 & $2 \cdot 4$ & - & - \\
\hline
\end{tabular}

Skin fibroblast extracts were incubated for 6 hours, amniotic fluid cell extracts for 16 hours, and organ extracts for 16-24 hours at $37^{\circ} \mathrm{C}$. At the end of the incubation period the sulphate released was determined by paper electrophoresis in a barbital-acetate- $\mathrm{N}$-cetyl pyridinium chloride buffer according to Kresse (1973).

For the determination of N-acetyl- $\alpha$-D-glucosaminidase activity $100 \mu \mathrm{l}$. cell homogenate were incubated for
6-15 hours at $37^{\circ} \mathrm{C}$ in the presence of $0.01 \mathrm{M}$ o-nitrophenyl- $\alpha-\mathrm{D}-\mathrm{N}$-acetylglucosaminide or $0.01 \mathrm{M}$ phenyl- $\alpha-$ $\mathrm{D}-\mathrm{N}$-acetylglucosaminide. At the end of the incubation period $\mathrm{N}$-acetylglucosamine liberated was determined by the Morgan-Elson reaction (Reissig, Strominger, and Leloir, 1959). Other glycoside hydrolases were determined as described by Werries, Pott, and Buddecke (1972).

FIG. 3. Electron micrographs of fetal liver showing hepatocytes and erythroblasts $(\times 3,600)$.

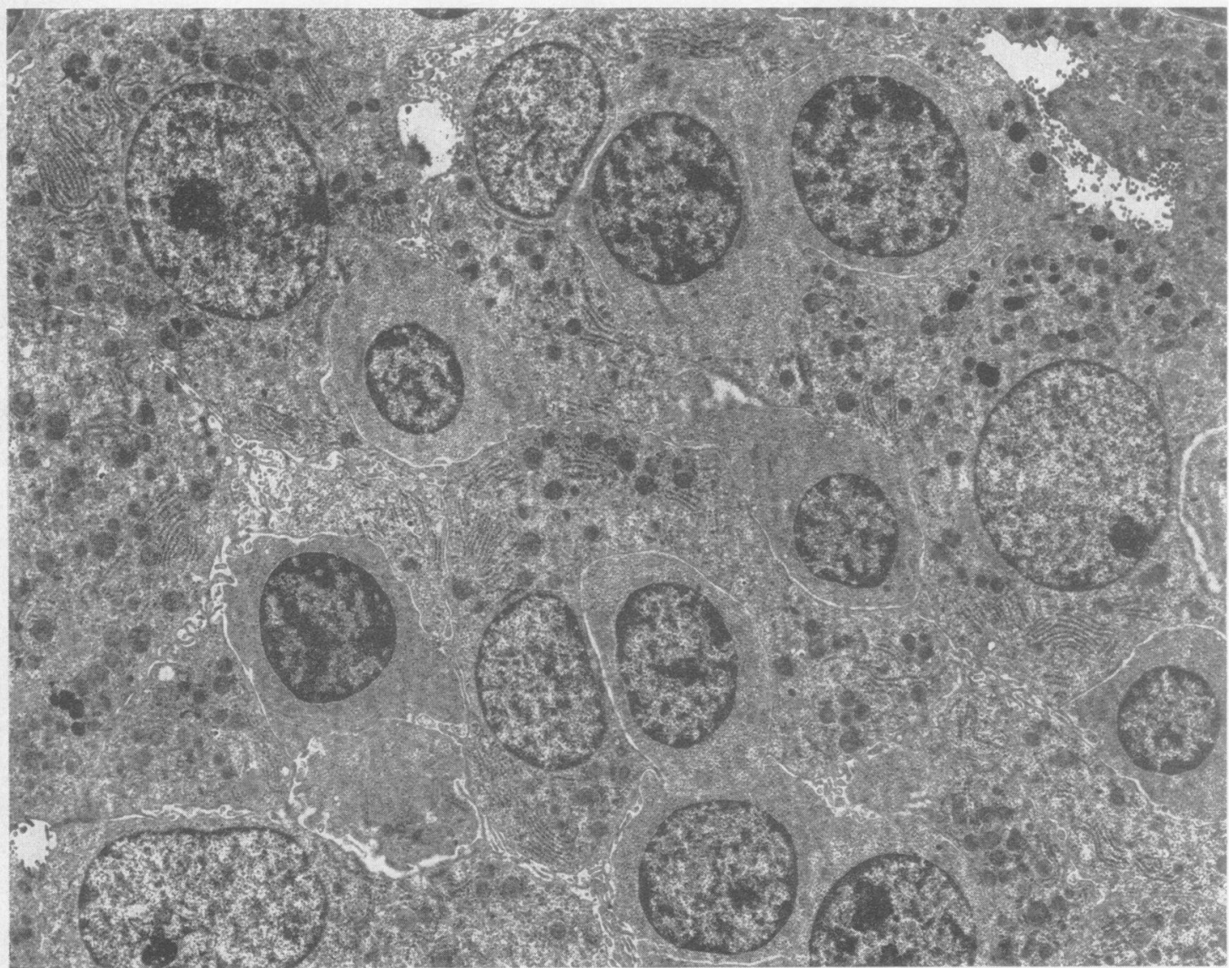

Fig. 3a. Normal fetus. Contents of hepatocytes evenly distributed. 


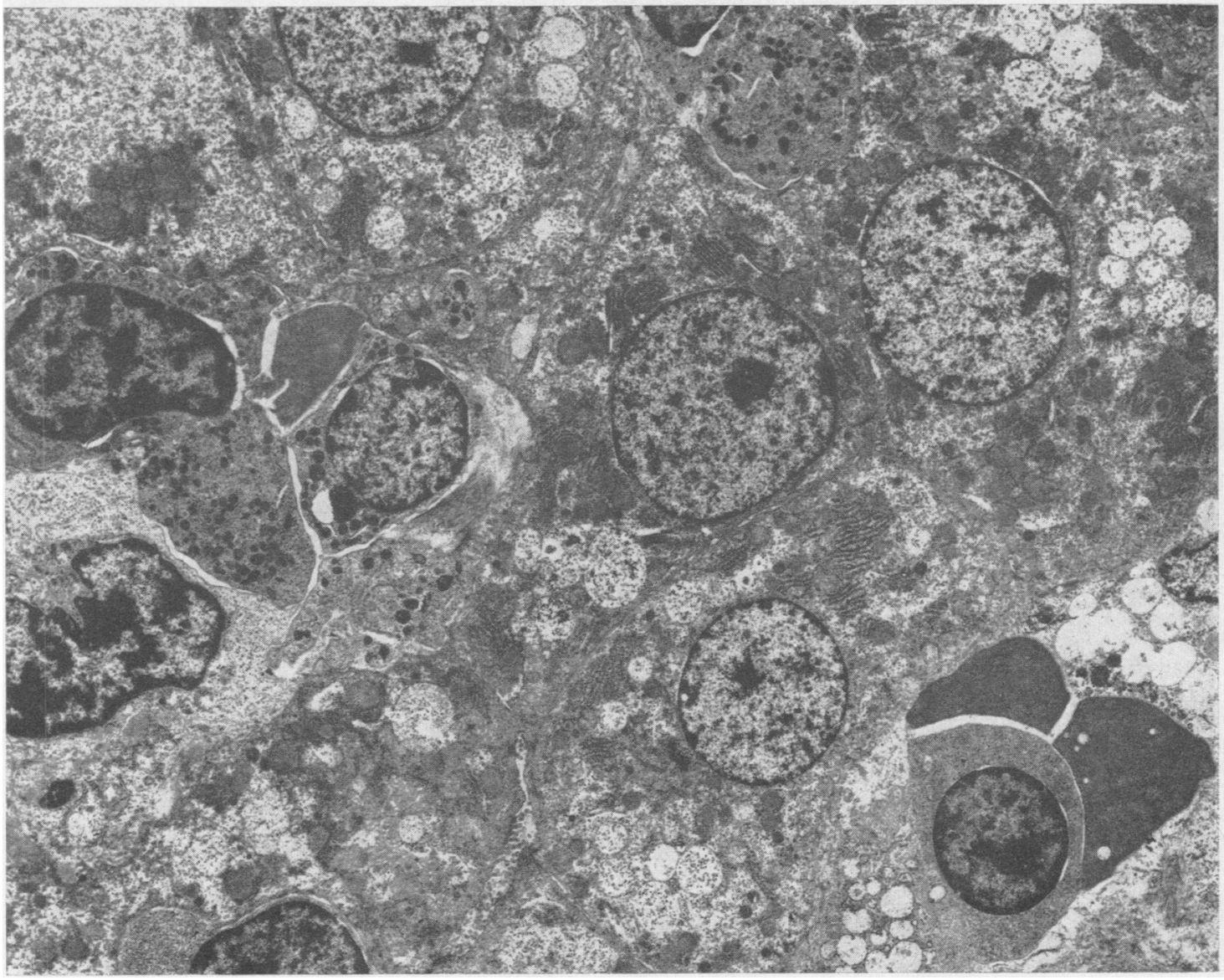

Fig. 3b. Affected fetus. Contents of hepatocytes interrupted by masses of electron-lucent, spherical inclusions.

TABLE IV

HEPARIN SULPHAMIDASE AND N-ACETYL- $\alpha$-D-GLUCOSAMINIDASE ACTIVITIES IN FETAL SKIN FIBROBLASTS AND AMNIOTIC FLUID CELLS

\begin{tabular}{|c|c|c|c|}
\hline \multirow[b]{2}{*}{$\begin{array}{l}\text { Skin fibroblasts } \\
\text { Fetus at risk } \\
\text { Control } \\
\text { Amniotic fluid cells } \\
\text { Fetus at risk } \\
\text { Control (32-week gestation) }\end{array}$} & \multirow{2}{*}{$\begin{array}{c}\begin{array}{c}\text { Heparin Sulphamidase } \\
\text { (pmol/mg protein/min) }\end{array} \\
0.21 \\
7.82 \\
0.20 \\
7.59\end{array}$} & \multicolumn{2}{|c|}{$\begin{array}{c}\text { N-acetyl- } \alpha-\mathrm{D}- \\
\text { Glucosaminidase } \\
(\mathrm{nmol} / \mathrm{mg} \text { protein } / \mathrm{min})\end{array}$} \\
\hline & & $\begin{array}{l}0.083^{*} \\
0.090^{*} \\
\text { nd } \\
0.366^{*}\end{array}$ & $\begin{array}{l}0.053 t \\
0.070 t \\
\text { nd } \\
0.291 t\end{array}$ \\
\hline
\end{tabular}

* o-Nitrophenyl- $\alpha-\mathrm{D}-\mathrm{N}$-acetylglucosaminide as substrate. + Phenyl- $\alpha-\mathrm{D}-\mathrm{N}$-acetylglucosaminide as substrate. nd $=$ not determined. 


\section{Results}

Mucopolysaccharide Analysis of Amniotic Fluid and Fetal Organs. The amniotic fluid mucopolysaccharides, analysed independently in three laboratories, are shown in Table II; all agree in showing a marked increase in mucopolysaccharide content and in particular in heparan sulphate, compared to normal samples.

The electrophoretic pattern is shown in Fig. 2. Fig. 2a shows absence of the well-marked hyaluronic acid component normally present at this stage of gestation and the presence of increased amounts of material with mobility slightly less than that of the heparan sulphate standard. Due to the diversity of molecular species of heparan sulphate, the mobility of material in subjects with Sanfilippo syndrome has sometimes been found to be less than that of the standard heparan sulphate preparation. In Fig. $2 b$ two-dimensional electrophoresis demonstrates a component in the fetus at risk with mobility comparable to that of heparan sulphate.

The mucopolysaccharide content of liver, brain, and spleen is given in Table III. The 30 -fold increase of heparan sulphate in the liver compared with the two-fold increase in the brain is of interest in view of the severe cerebral damage and lack of clinical hepatic involvement in the Sanfilippo syndrome.

Histological and Electronmicroscopic Studies of Fetal Organs and Cultured Cells. The female fetus (PM.CH.20/73) weighed $970 \mathrm{~g}$ and measured $25 \mathrm{~cm}$ in crown/rump and $36 \mathrm{~cm}$ in crown/heel length. It showed no gross external or internal abnormalities, with solid organs all being

Fig. 4. Electron micrographs of cultured fetal skin fibroblast $(\times 8,600)$.

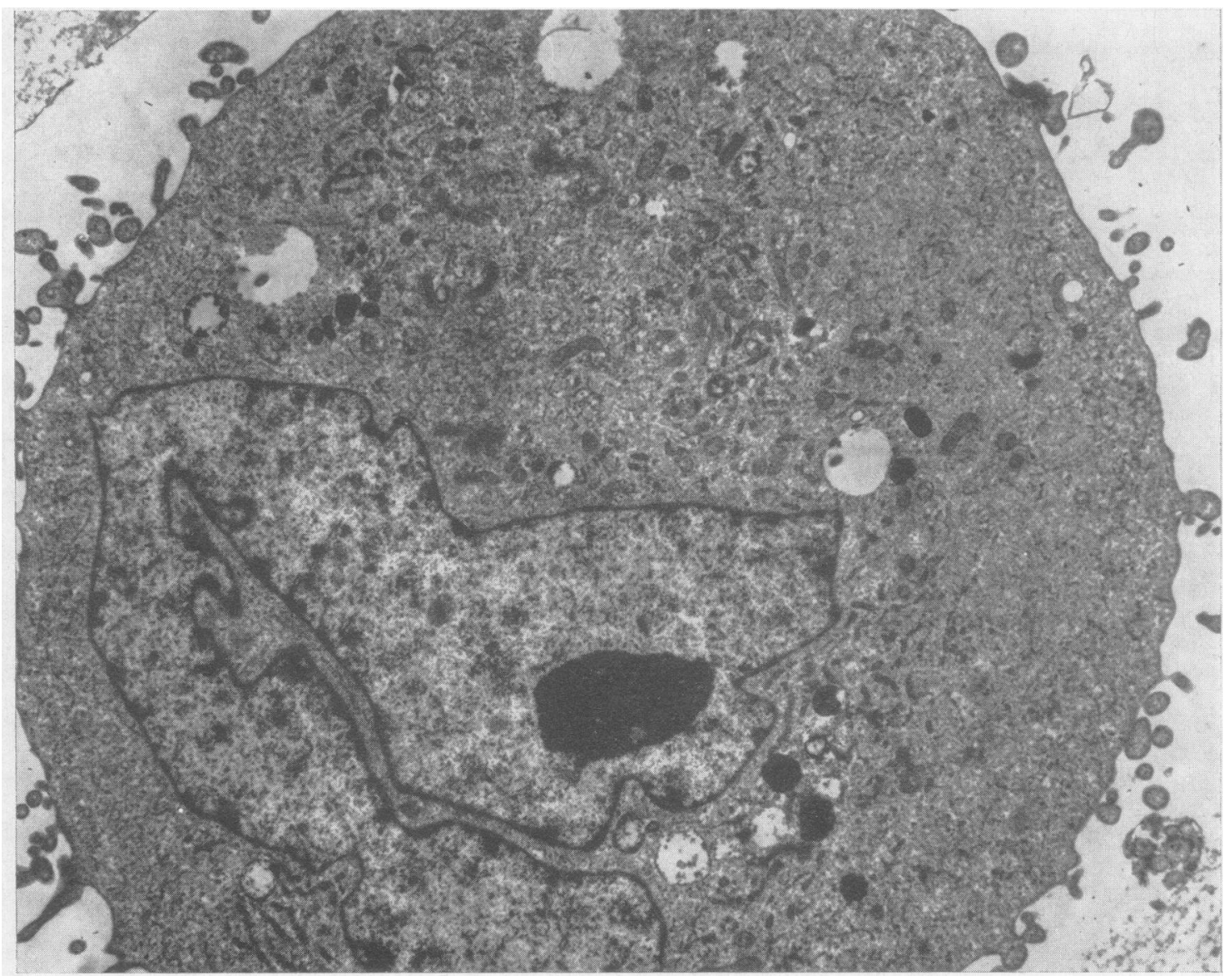

FIG. 4a. Normal fetus. Cytoplasm densely granular, with a normal complement of organelles. 


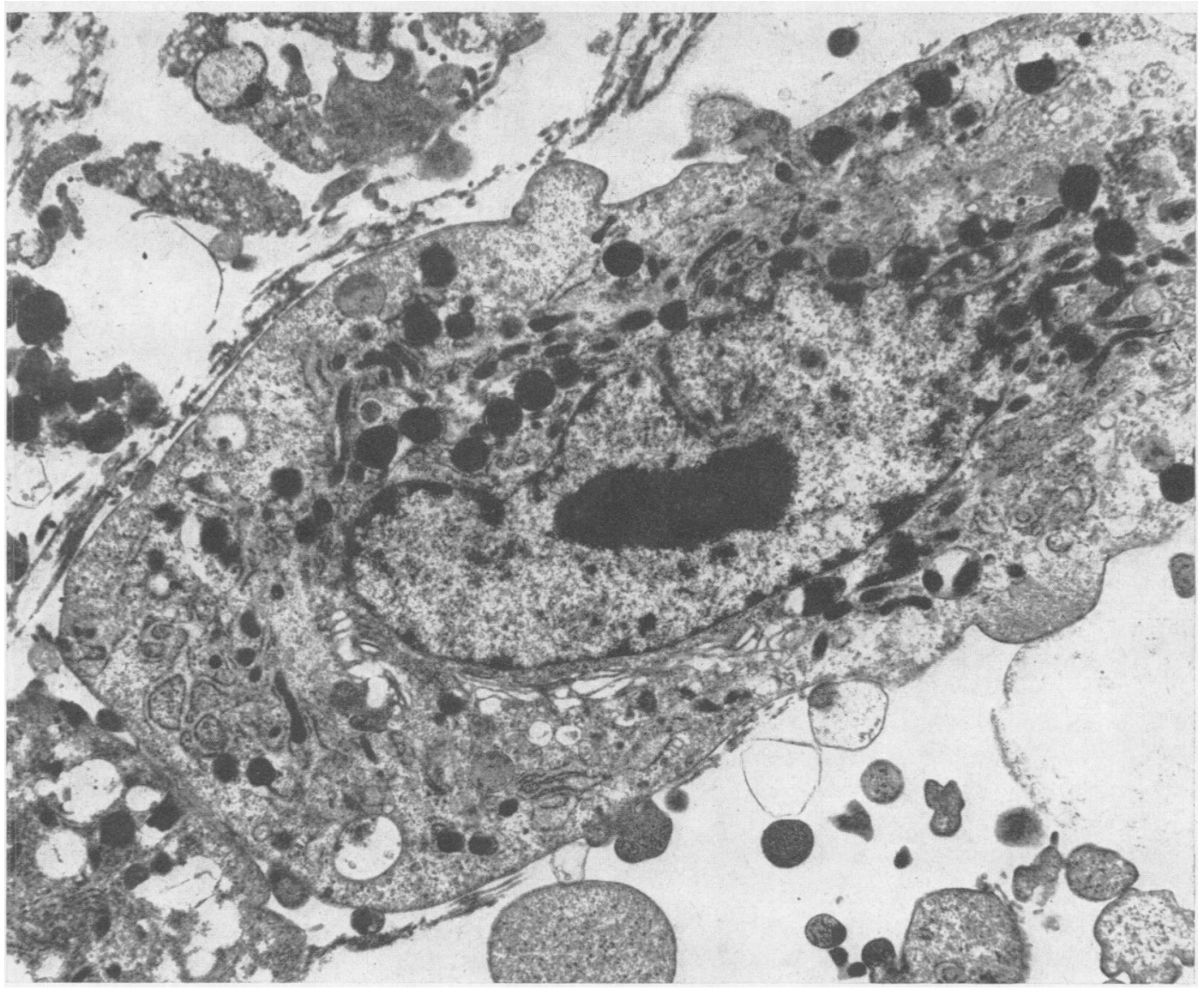

FIg. 4b. Affected fetus. Cytoplasm electron-lucent, with extensive Golgi complex and numerous lysosome-like, densely osmiophilic bodies.

of normal weight (lungs $14 \mathrm{~g}$, heart $5 \mathrm{~g}$, liver $44 \mathrm{~g}$, thymus $4 \mathrm{~g}$, suprarenals $1.8 \mathrm{~g}$, kidneys $5 \mathrm{~g}$, and brain $112 \mathrm{~g}$ ).

Histological examination (using haematoxylin and eosin, cresyl fast violet, toluidine blue, periodic acid-Schiff, and alcian blue at both $\mathrm{pH} 1$ and $\mathrm{pH} 2.5$ ) of all internal organs as well as cerebral cortex, basal nuclear complex, cerebellum, pons medulla, spinal cord and spinal root ganglia, nerves, lymph glands, muscle, bone, and cartilage, did not reveal structural abnormalities nor any abnormal mucopolysaccharide or other constituent. The electronmicroscopic appearance of the liver of the at risk fetus and a normal control fetus are shown in Fig. 3. Cytoplasmic inclusion bodies distending the hepatocytes are demonstrated. Abnormal inclusions are also seen in the cultured fibroblasts (Fig. 4). A full report of electronmicroscopic findings is to follow (G. R. Newman, in preparation).

Cellular Incorporation of ${ }^{35}$ Sulphate. Figure 5 shows the uptake of ${ }^{35} \mathrm{~S}$ inorganic sulphate by cultured skin fibroblasts of the at risk fetus compared with those of a normal fetus of 17 weeks' gestation. Continued accumulation of isotope is seen at 4 days, in contrast to the levelling off in the control cells, suggesting failure of release of mucopolysaccharide from the lysosomal pool.

Determination of Heparin Sulphamidase and Glycoside Hydrolases. Figure 6 shows that fibroblasts cultured from the skin of the fetus at risk for the Sanfilippo syndrome do not release inorganic sulphate from heparin- $-{ }^{35} \mathrm{SO}_{4}$ in significant amounts. Fibroblasts from a control fetus exhibit 
TABLE V

ACTIVITIES OF HEPARIN SULPHAMIDASE AND DIFFERENT GLYCOSIDE HYDROLASES IN FETAL ORGANS

\begin{tabular}{|c|c|c|c|c|c|}
\hline . & $\underset{\text { Sulphamidase* }}{\text { Heparin }}$ & $\begin{array}{l}\text { N-acetyl- } \alpha-D- \\
\text { Glucosaminidaset }\end{array}$ & $\begin{array}{l}\text { N-acetyl- } \beta-D- \\
\text { Glucosaminidase }\end{array}$ & $\beta$-D-Galactosidase $\dagger$ & B-D-Glucuronidaset \\
\hline $\begin{array}{l}\text { Heart } \\
\text { Fetus at risk } \\
\text { Control }\end{array}$ & $\begin{array}{l}0.030 \\
0.889\end{array}$ & $\begin{array}{l}0.080 \\
0.073\end{array}$ & $\begin{array}{r}118 \\
43\end{array}$ & $\begin{array}{l}0.99 \\
1.77\end{array}$ & $\begin{array}{l}0.095 \\
0.316\end{array}$ \\
\hline $\begin{array}{l}\text { Lung } \\
\text { Fetus at risk } \\
\text { Control }\end{array}$ & $\begin{array}{l}0 \cdot 043 \\
0.347\end{array}$ & $\begin{array}{l}0 \cdot 103 \\
0.065\end{array}$ & $\begin{array}{r}245 \\
60\end{array}$ & $\begin{array}{l}0.49 \\
1.05\end{array}$ & $\begin{array}{l}0 \cdot 153 \\
0 \cdot 183\end{array}$ \\
\hline $\begin{array}{l}\text { Brain } \\
\text { Fetus at risk } \\
\text { Control }\end{array}$ & $\begin{array}{l}0.033 \\
0.235\end{array}$ & $\begin{array}{l}0.050 \\
0.057\end{array}$ & $\begin{array}{l}29 \\
28\end{array}$ & $\begin{array}{l}0.41 \\
0.43\end{array}$ & $\begin{array}{l}0.052 \\
0.305\end{array}$ \\
\hline $\begin{array}{l}\text { Adrenal gland } \\
\text { Fetus at risk } \\
\text { Control }\end{array}$ & $\begin{array}{l}0.015 \\
1.390\end{array}$ & $\begin{array}{l}0 \cdot 119 \\
0.081\end{array}$ & $\begin{array}{l}220 \\
136\end{array}$ & $\begin{array}{l}4 \cdot 45 \\
9 \cdot 03\end{array}$ & $\begin{array}{l}0 \cdot 091 \\
0 \cdot 188\end{array}$ \\
\hline $\begin{array}{l}\text { Small intestine } \\
\text { Fetus at risk }\end{array}$ & $0 \cdot 112$ & 0.249 & 368 & $1 \cdot 67$ & $0 \cdot 235$ \\
\hline $\begin{array}{l}\text { Placenta } \\
\text { Fetus at risk }\end{array}$ & 0.067 & 0.348 & 18 & $0 \cdot 10$ & 0.311 \\
\hline
\end{tabular}

* Expressed as pmol/mg protein/min.

+ Expressed as nmol/mg protein/min.

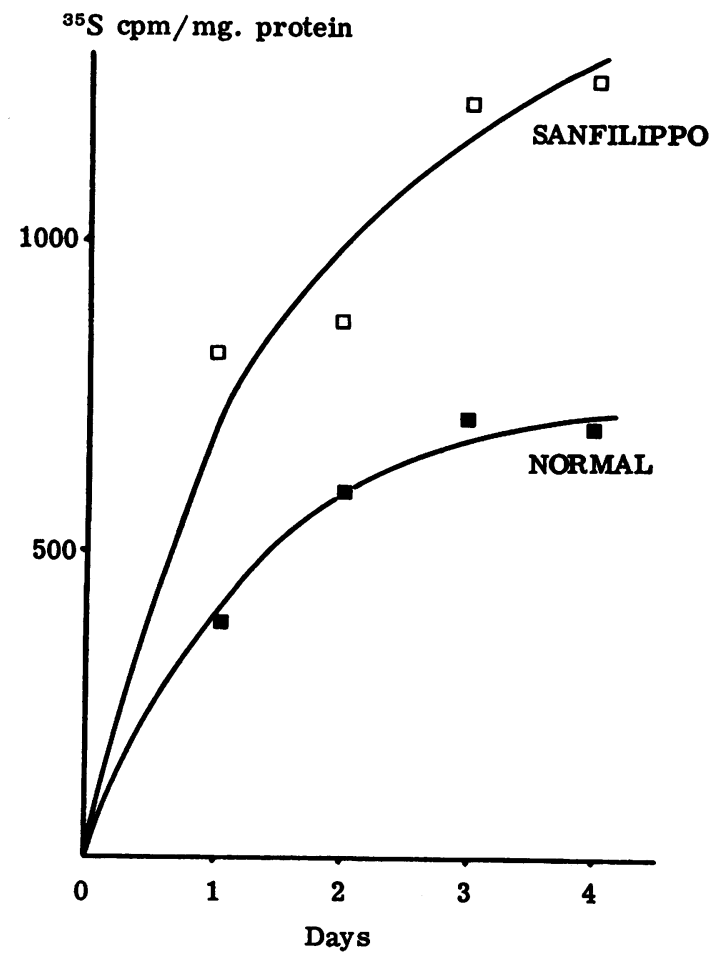

Fig. 5. ${ }^{35} \mathrm{~S}$ uptake of cultured fibroblasts from affected and normal fetus. normal sulphamidase activity (Table IV). For eight skin fibroblast lines of other than Sanfilippo A genotype the mean heparin sulphamidase activity was $9.41 \pm 2.55 \mathrm{pmol} / \mathrm{mg}$ protein $/ \mathrm{min}$, whereas five Sanfilippo A cell lines had an activity of 0.30 \pm 0.19 $\mathrm{pmol} / \mathrm{mg}$ protein/min (Kresse, 1973).

Since essentially normal values for $\mathrm{N}$-acetyl- $\alpha-\mathrm{D}$ glucosaminidase activity have been measured in skin fibroblasts of the fetus at risk, the results obtained establish the diagnosis of Sanfilippo A disease. This was confirmed by correction studies kindly carried out by Dr Elizabeth Neufeld on cultured fetal skin fibroblasts.

The deficiency of heparin sulphamidase activity was also found in cultured amniotic fluid cells. Shortage of material prevented the determination of $\mathrm{N}$-acetyl- $\alpha$-D-glucosaminidase activity in those cells.

The deficiency of a heparin sulphamidase can also be demonstrated in organ extracts of the affected fetus (Table V). The somewhat higher residual activity compared with skin fibroblasts and amniotic fluid cells might be due to the existence of sulphamidase isoenzymes, the presence of which has not yet been investigated. It should be noted that heparin$\mathrm{N}-{ }^{35} \mathrm{SO}_{4}$ contains some labelled $\mathrm{O}$-sulphate groups which could be removed by the action of a heparin sulphate ester sulphatase.

The measurements of $\mathrm{N}$-acetyl- $\beta$-D-glucosaminidase, $\beta$-D-galactosidase and $\beta$-D-glucuronidase show that the secondary activity changes of lysosomal hydrolases in the mucopolysaccharidoses which have been reported in the past, are already present to some extent during fetal life. In the brain, however, in which only a moderate increase of 


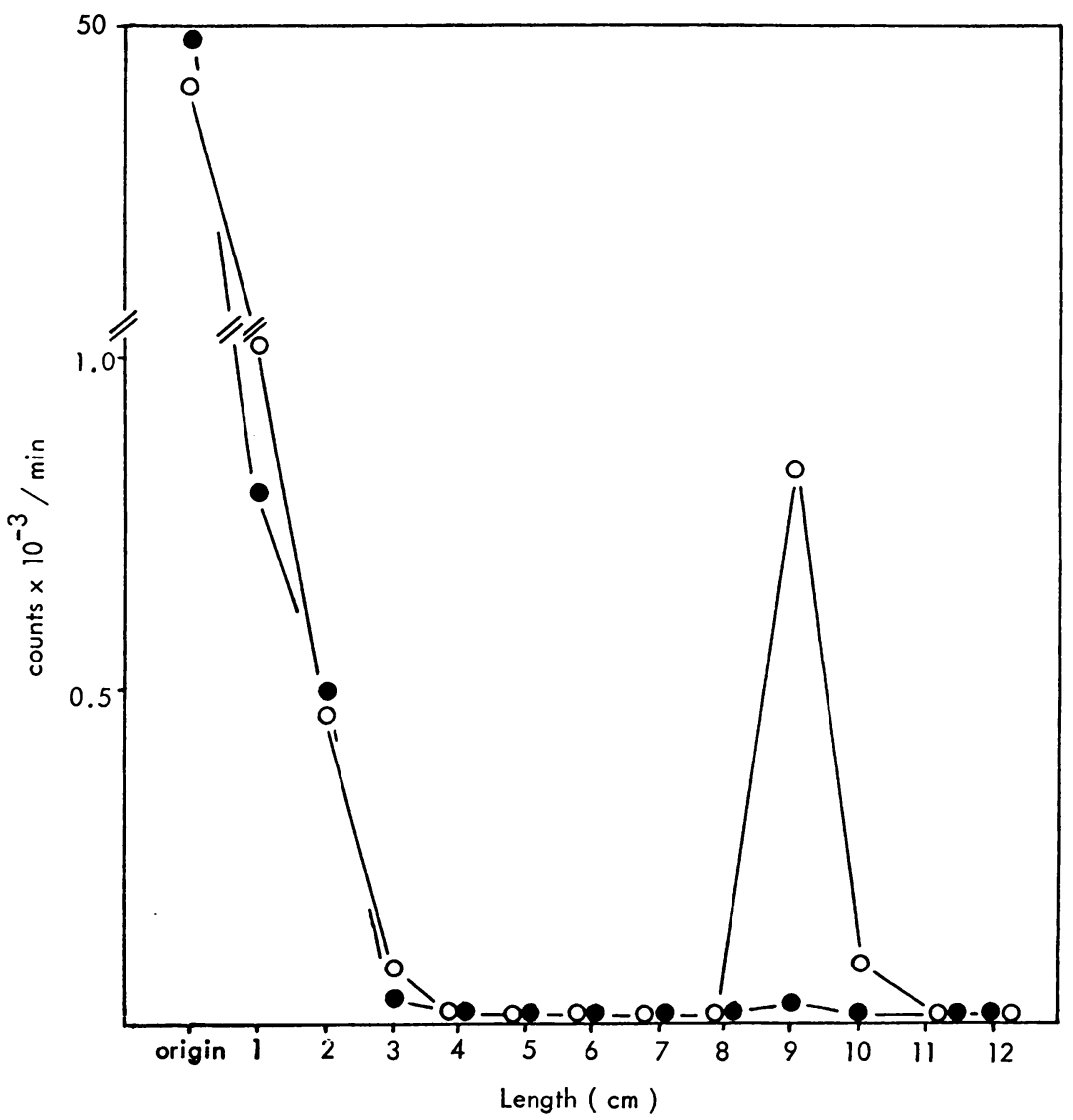

FIG. 6. Electrophoretic pattern of heparin-N-35 $\mathrm{SO}_{4}$ after incubation with skin fibroblast homogenates from a fetus at risk for Sanfilippo syndrome ( $\longrightarrow$ ) and from a normal control $(\mathrm{O}-\mathrm{O})$.

heparan sulphate content has been observed, normal $\mathrm{N}$-acetyl- $\beta$-D-glucosaminidase and $\beta$-D-galactosidase activities were found. Kint et al (1973) have suggested that the activity of lysosomal enzymes is altered by excessive storage of acid mucopolysaccharides.

\section{Discussion}

Various techniques for prenatal diagnosis of mucopolysaccharidoses, especially the determination of mucopolysaccharide content in the amniotic fluid and the pattern of ${ }^{35} \mathrm{SO}_{4}$ incorporation into amniotic cells, have been attempted.

The analysis of total mucopolysaccharide content of amniotic fluid and their fractionation, which avoids the uncertainty of growth of amniotic cells and the delay involved, bears the risk of false negative results. Matalon et al (1970) reported raised total mucopolysaccharide content of amniotic fluid at 14 weeks' gestation in a pregnancy affected by Hurler disease, and also found a high proportion of heparan sulphate, not detectable in normal samples. Subsequently, however, they found normal levels of mucopolysaccharide in two abnormal pregnancies; one studied at 10 weeks' gestation, resulted in an infant with Sanfilippo syndrome; the other, at risk for Hunter disease, was later shown to have abnormal ${ }^{35} \mathrm{SO}_{4}$ cellular uptake, and a termination was performed (Matalon, Dorfman, and Nadler, 1972). Brock et al (1971) also found normal values at 18 weeks in a pregnancy resulting in a child with Hurler disease. Nevertheless an abnormal result may be of great value, particularly in more advanced pregnancies where, as in the present case, there may not be time to study cultured cells before the decision has to be made whether or not to terminate the pregnancy. Details of variation in the 
acid mucopolysaccharide content of amniotic fluid throughout pregnancy have been given by Duncan et al (1973).

Using the method of measuring the ${ }^{35} \mathrm{SO}_{4}$ uptake of cultured amniotic cells no misdiagnosis has been reported so far. Successful prenatal diagnoses of Hurler and Hunter diseases have been reported by Fratantoni et al (1969) and Crawfurd et al (1973).

Because of the late onset of clinical symptoms in the Sanfilippo syndrome the possibility of its prenatal diagnosis was not predictable. The results reported in this paper, which were obtained by various techniques in different laboratories, leave no doubt that the fetus exhibited an abnormal heparan sulphate metabolism at the 25 th week of pregnancy.

In addition to the above mentioned methods, the determinations of heparin sulphamidase and $\mathrm{N}$ acetyl- $\alpha-D$-glucosaminidase activities were used for the first time to establish prenatal diagnosis. The present case was shown to be type $A$ by the profound deficiency of heparin sulphamidase in all tissues investigated, whereas the $\mathrm{N}$-acetyl- $\alpha$-D-glucosaminidase activity was normal. Correction tests confirmed the enzymatic diagnosis.

We are indebted to Dr Elizabeth Neufeld of National Institutes of Health, Bethesda, USA for allowing us to report the results of correction experiments performed on cells sent to her, and for her helpful criticism of the manuscript; to Dr G. R. Newman and Mrs A. K. Price who carried out the electronmicroscopic studies; to $\mathrm{Mr}$ Norman Stark, Mr O. Oladimeji, Mr P. Gregory, and Miss Helen Langmaid for assistance in preparation and culture of the samples. We are grateful to Dr A. Griffiths and Dr J. Dodge who were responsible for care of the elder sib, to Mr L. A. Ogilvie who performed the termination, and to Professors O. P. Gray and R. Mahler for their encouragement and suggestions.

Financial assistance for this work was provided by the Deutsche Forschungsgemeinschaft, the Clinical Research Committee of the Welsh Hospital Board, and the Western Regional Hospital Board, Scotland.

\section{REFBRENCES}

Bitter, T. and Muir, H. (1962). A modified uronic acid carbazole reaction. Analytical Biochemistry, 4, 330-334.

Brock, D. J. H., Gordon, H., Seligman, S., and Lobo, E. de H. (1971). Antenatal detection of Hurler's syndrome. Lancet, 2, 1324-1325.
Crawfurd, M. d'A., Dean, M. F., Hunt, D. M., Johnson, D. R., MacDonald, R. R., Muir, H., Payling Wright, E. A., and Payling Wright, C. R. (1973). Early prenatal diagnosis of Hurler's syndrome with termination of pregnancy and confirmatory findings on the fetus. Fournal of Medical Genetics, 10, 144-153.

Duncan, D. M., Logan, R. W., Ferguson-Smith, M. A., and Hall, F. (1973). The measurement of acid mucopolysaccharides (glycosaminoglycans) in amniotic fluid and urine. Clinica Chimica Acta, 45, 73-83.

Ferguson-Smith, M. A., Duncan, D. M., Logan, R. W., Hall, F., Wusteman, F. S., and Harper, P. S. (1973). Antenatal diagnosis of mucopolysaccharidoses. Lancet, 2, 45-46.

Fratantoni, J. C., Hall, C. W., and Neufeld, E. F. (1968). Defect in Hurler's and Hunter's syndromes: faulty degradation of mucopolysaccharide. Proceedings of the National Academy of Science, 60, 699-706.

Fratantoni, J. C., Neufeld, E. F., Uhlendorf, B. W., and Jacobson, C. B. (1969). Intrauterine Diagnosis of the Hurler and Hunter syndromes. New England Fournal of Medicine, 280, 686-688.

Kint, J. A., Dacremont, G., Carton, D., Orye, E., and Hooft, C. (1973). Mucopolysaccharidosis: Secondarily induced abnormal distribution of lysosomal isoenzymes. Science, 181, 352-354.

Kresse, H. (1973). Mucopolysaccharidosis III A (Sanfilippo A disease): deficiency of a heparin sulphamidase in skin fibroblasts and leucocytes. Biochemical and Biophysical Research Communications, 54, 1111-1118.

Kresse, H. and Neufeld, E. F. (1972). The Sanfilippo A corrective factor: purification and mode of action. Fournal of Biological Chemistry, 247, 2164-2170.

Kresse, H., Wiesmann, U, Cantz, M., Hall, C. W., and Neufeld, E. F. (1971). Biochemical heterogeneity of the Sanfilippo syndrome: preliminary characterization of two deficient factors. Biochemical and Biophysical Research Communications, 42, 887-892.

Lagunoff, D. and Warren, G. (1962). Determination of 2-deoxy-2 sulphoaminohexose content of mucopolysaccharides. Archives of Biochemistry and Biophysics, 99, 396.

Lowry, O. H., Rosebrough, N. J., Farr, A. L., and Randall, R. J. (1951). Protein measurement with the folin phenol reagent. fournal of Biological Chemistry, 193, 265-275.

Matalon, R., Dorfman, A., and Nadler, H. L. (1972). A chemical method for the antenatal diagnosis of mucopolysaccharidoses. Lancet, 1, 798-799.

Matalon, R., Dorfman, A., Nadler, H. L., and Jacobson, C. B. (1970). A chemical method for the antenatal diagnosis of mucopolysaccharidoses. Lancet, 1, 83-84.

O'Brien, J. S. (1972). Sanfilippo syndrome: profound deficiency of alpha-acetyl-glucosaminidase activity in organs and skin fibroblasts from type B patients. Proceedings of the National Academy of Sciences, 69, 1720-1722.

Reissig, J. L., Strominger, J. L., and Leloir, L. F. (1959). A modified colorimetric method for the estimation of $\mathrm{N}$-acetylamino sugars. Fournal of Biological Chemistry, 217, 959-966.

Scott, J. E. (1960). Aliphatic ammonium salts in the assay of acid polysaccharides from tissues. Methods of Biochemical Analysis, 8, 145-197.

Figura, K. von and Kresse, H. (1972). The Sanfilippo B corrective factor: An N-acetyl- $\alpha$-D-glucosaminidase. Biochemical and Biophyscal Research Communications, 48, 262-269.

Weissmann, B. (1966). Preparation of 2-acetamido-2-deoxy- $\alpha$ glycopuranosides. Fournal of Organic Chemistry, 31, 2505-2509.

Werries, E., Pott, G., and Buddecke, E. (1972). Bestimmung des Glykosidaseaktivitätsverteilungsmusters in Biopsiematerial menschlicher Organe und in Hautfibroblasten. In Fortschritte der Klinischen Chemie, Enzyme und Hormone, ed. by E. Kaiser, pp. 7380. Academy of Medicine, Vienna.

Whiteman, P. (1973). Prenatal diagnosis of mucopolysaccharidoses. Lancet, 1, 1249. 